\title{
Stanisław Grodziski
}

Uniwersytet Jagielloński

telefon: +48124221032

DOI: $10.15290 /$ mhi.2015.14.01.11

\section{Uwagi o planach reformatorskich króla Jana Kazimierza}

\author{
SUMMARY \\ Remarks on the Reformatory Plans of King John Casimir
}

The article presents the reformatory ideas of King John Casimir in the years 1655-1658. They are worth mentioning, although they had no chance of being realized.

Due to the danger of war the King proposed that the military obligation should be exceeded not only on noblemen, but the Sejm should impose it on representatives of lower estates. The towns should have been transformed into "fortresses of the Commonwealth", well prepared for effective defence. Also peasants would have to bear new military obligation, by serving in the re-modelled "Lands' infantry". In his oath on April 1st, 1656 the King pronounced a considerable limitation of feudal obligations over peasants, such as serfdom. After the war with Sweden he didn't return to these ideas.

In the field of the Commonwealth's political system, the King proposed limitation of the "liberum veto" system in the Sejm and the reform of free election of the King. These proposals, especially the idea of the election "vivente rege", i.e. the election of the King during the reign of the previous monarch, were strongly contested by noblemen. King John Casimir decided to abdicate.

Key words: John II Casimir, reforms, liberum veto, election "vivente rege", abdication

Słowa kluczowe: Jan II Kazimierz, reformy, liberum veto, elekcja vivente rege, abdykacja

Tematem tego szkicu są reformatorskie działania króla Jana Kazimierza Wazy w latach 1656-1658, to jest w czasach szwedzkiego najazdu ${ }^{1}$. Badacze tej

1 Refleksje na ten temat nasunęly się autorowi podczas przygotowania do druku kolejnego tomu edycji Volumina Constitutionum, to jest tomu IV, volumen 1, obejmującego dorobek normatywny Sejmu Rzeczypospolitej w latach 1641-1658. 
epoki planów i działań królewskich nie pomijali; zazwyczaj jednak, jako nie uwieńczonych powodzeniem, nie oceniali ich zbyt szczegółowo. Przyjmowali tylko ogólnie, iż los nie oszczędził wielkich zadań temu małemu człowiekowi.

Warto bowiem zastanowić się nad sytuacją, kiedy monarcha dobrze orientował się, co czynić powinien, ale jednak tego nie czynił. Niejedno z takich zaniechań przypisać można królowi Janowi Kazimierzowi.

Czasy, o których tu mowa, były już przedmiotem wyczerpujących i wartościowych opracowań kilku pokoleń badaczy. Nie pomijano osobistego wkładu Jana Kazimierza w bieg wydarzeń. Przebadane zostało całe życie tego monarchy, przed objęciem tronu, w czasie jego dwudziestoletniego, burzliwego panowania, wreszcie po abdykacji². $W$ tym więc szkicu przedstawiono nieco inną niż przyjęto dotychczas ocenę polityki Jana Kazimierza, zwłaszcza w latach 1656-1658, kiedy tę „politykę straconych okazji” przyćmiewały liczne ważne wydarzenia.

W ówczesnej opinii szlacheckiej obraz tego monarchy, od samego niemal początku jego panowania był negatywny ${ }^{3}$. Monogram króla: ICR (Ioannes Casimirus Rex) odczytywano jako Initium calamitatis Regni - początek nieszczęścia Królestwa. Tym samym uczyniono króla osobiście odpowiedzialnym za całe pasmo niepowodzeń, choćby zdarzyły się one przed objęciem przezeń panowania i trwały nadal aż do jego abdykacji, a nawet i po niej. Nie brakło takich, którzy domagali się, by wypowiedzieć mu posłuszeństwo. Ci nie mogli mu wybaczyć, że ich ubiegł i sam ustąpił z tronu.

Jedynie w kręgach wojskowych osądzano Jana Kazimierza pozytywnie. Zdawano sobie sprawę z jego uzdolnien, wykazanych podczas niejednej kampanii, a także ceniono jego osobistą odwagę; dawał temu wyraz świadek tych wydarzeń, Jan Chryzostom Pasek ${ }^{4}$

W środowisku naukowym poczynając już od połowy XIX w., przeważała opinia krytyczna. Dopiero z końcem tego wieku lepszą ocenę narzuciła społeczeństwu literatura piękna, przede wszystkim Henryk Sienkiewicz. Charakterystykę monarchy, sugestywnie przezeń odmalowaną w Potopie, podzielać też poczęli niektórzy badacze. Pytanie, czy w pełni słusznie?

2 Z bogatej literatury, poświęconej temu władcy wymienione tu zostaną tylko nowsze, i zdaniem autora, ważniejsze pozycje. Biogram Jana Kazimierza pióra Władysława Czaplińskiego, zamieszczony w Polskim stowniku biograficznym (t. X, s. 410-413) zawiera wykaz wcześniejszej literatury. Por. też: T. Wasilewski, Ostatni Waza na polskim tronie, Katowice 1984; Z. Wójcik, Jan Kazimierz Waza, Wrocław 1997.

3 Z. Wójcik, op. cit., s. 59 i n. podkreślał, iż Jan Kazimierz już od Sejmu koronacyjnego drażnił swym zachowaniem szlachtę i narażał się poszczególnym magnatom. W późniejszych latach, choć wykazał odwagę pod Zborowem i doskonale dowodził pod Beresteczkiem, był surowo krytykowany za nieudaną kampanię pod Żwańcem. Dobrze też dowodził pod Warszawą.

4 Wspominał on Jana Kazimierza kilkakrotnie z sympatią. Por. Jan Chryzostom z Gosławic Pasek: Pamiętniki, wyd. J. Czubek, PAU, Kraków 1929, zwłaszcza s. 371-373. 
Obecnie upowszechniło się przekonanie, iż Jan Kazimierz zdawał sobie sprawę z wad ustroju polskiego, ale bądź nie potrafił stanąć na czele zwolenników reform, bądź jego działania były niekonsekwentne i nieskuteczne ${ }^{5}$. Zapewne - może i pod wpływem królowej Marii Ludwiki - był przekonany, iż jedynym lekarstwem na polskie wady ustrojowe byłby absolutyzm. Niełatwo przychodziło mu jednać sobie przyjaciół; przeciwnie natomiast, często mnożył sobie wrogów wśród magnatów, narażał się opinii szlacheckiej.

W polityce wewnętrznej, w codziennych działaniach słaby, a nawet kapryśny, ulegał wpływom swoich doradców. Przynosiło to korzyści jeśli takim doradcą był kanclerz Jerzy Ossoliński, ale doprowadziło to do katastrofy, gdy była to królowa Maria Ludwika. Pragnęła ona bowiem zrealizować projekt elekcji za życia swego małżonka, i to elekcji zapewniającej tron kandydatowi francuskiemu. Środowisko szlacheckie elekcji viviente rege było przeciwne, a bardzo już było niechętne kandydatowi z Francji. Obawiano się nie bez podstaw, iż będzie on dążył do absolutyzmu; pamiętano też jeszcze, jaką zniewagę wyrządził Rzeczypospolitej Henryk Walezjusz, porzucając tron polski.

Przyjrzyjmy się teraz decyzjom królewskim, związanym z pasmem klęsk, które przeszły do historii pod nazwą „potopu”. Choć trwała wojna wzdłuż całej ściany wschodniej, rozpoczął się najazd szwedzki. Kapitulacja pod Ujściem i dalsze klęski poniesione podczas prób zatrzymania wojsk szwedzkich maszerujących na południe, wreszcie utrata Krakowa spowodowały, że Jan Kazimierz porzucił Polskę i schronił się na habsburskim Śląsku. Magnaci i szlachta, przyjmujący „protekcję” króla Karola Gustawa, nie zdawali sobie sprawy z tego, że była to namiastka elekcji, i to vivente rege. Nadto ta w żadnym wypadku nie mogła być nazwana „wolną".

Dopiero z końcem 1655 r. obrona Częstochowy i rozwój antyszwedzkiej, głównie chłopskiej, partyzantki spowodowały, że król powrócił i organizować począł obronę. 1 kwietnia 1656 r. Jan Kazimierz ślubował w Katedrze lwowskiej, iż Matka Boska staje się Królową Korony Polskiej. Nadawało to wojnie charakter religijny, między katolicką Polską a luterańską Szwecją, mobilizowało opór, a jednocześnie - co zaznaczyło się już na Sejmie 1658 r. - ograniczało tolerancję religijną. Nadto, z uwagi na ogromne znaczenie partyzantki chłopskiej, król ślubował iż „po otrzymaniu pokoju wraz z wszystkimi stany wszelkich miar użyje, by lud polski od uciążliwości niesłusznych i ucisku wyzwolić"6.

Sformułowania Ślubów oznaczały, iż król postanowił otoczyć chłopów opieką prawa i ulżyć ich powinnościom. Nie mógł jednak nie zdawać sobie sprawy z tego, iż nie miał żadnej władzy, która umożliwiłaby mu jakieś

5 Nie zawsze też były szczere. Król wprawdzie potępiał zerwanie Sejmu w 1652, ale już Sejm w $1654 \mathrm{r}$. został zerwany z inicjatywy dworu.

6 Tekst lwowskich ślubów Jana Kazimierza. Por. Panowanie Jana Kazimierza. Teksty źódłowe, Kraków 1924 r., s. 26. Przedruk za Augustynem Kordeckim, Nowa Gigantomachia, wyd. z 1859, s. 48-49. 
ogólne obniżenie pańszczyzny. Mógł jedynie obniżyć tę pańszczyznę w swoich dobrach stołowych i szerzej objąć włościan w królewszczyznach opieką sądu referendarskiego. Tego jednak nie zrobił; można więc stwierdzić, że nie miał żadnej koncepcji, w jaki sposób dokonać tego ulżenia doli włościańskiej. Nie próbował także nobilitować jakichś zasłużonych przywódców chłopskiej partyzantki; tym bardziej zwraca to uwagę, iż król zamierzał nadal korzystać z chłopskiej siły zbrojnej, czyli piechoty łanowej.

Królewskie zobowiązanie, zaciągnięte w Katedrze lwowskiej 1 kwietnia 1656 r., pominięte zostało przez sejmy, innymi sprawami zajęte $\mathrm{w}$ latach 1658-16607. Pominięte też zostało przez Jana Kazimierza, który zaniedbał „użyć wszelkich miar" nawet w stosunku do królewszczyzn. Łatwo przyszło mu podzielić przekonanie szlachty, że klęski, jakie spotkały Rzeczpospolitą nie były wynikiem zdrady ani skutkiem wad jej ustroju społecznego i politycznego. Stanowiły one natomiast karę bożą za szerzenie się arianizmu, popieranie prawosławia i tolerancję wobec zwolenników reformacji.

Jeszcze raz przyjrzeć się należy sytuacji stanu włościańskiego. Problem ten pojawił się dla monarchy nie w chwili składania ślubów w Katedrze lwowskiej, ale już w momencie, gdy obejmował władzę w czasie powstania Chmielnickiego, gdy tego doświadczonego wodza poparły masy chłopskie na Ukrainie, a także pojawily się wyraźne przejawy oporu na Podhalu i nawet w Wielkopolsce - one też były jednym z powodów, że szlachta uczestnicząca w pospolitym ruszeniu porzucała pole walki natychmiast po Beresteczku, obawiając się zagrożenia u siebie.

Sprawa włościańska stanęła pod obrady w 1654 r., gdy - w czasie trwającej ciągle wojny na wschodzie, zagroził szwedzki najazd z zachodu. Sejm, który obradował 19 V 1655 r., czyli na miesiąc przed kapitulacją pod Ujściem, uchwalił pospolite ruszenie, ale nie potraktował go tak, jak tego wymagała sytuacja. Wojska Karola Gustawa wylądowały już pod Szczecinem i maszerowały ku Wielkopolsce, a Sejm nie uchwalił jeszcze trzecich wici, wyliczając natomiast, kogo z góry należy zwolnić z udziału w wyprawie ${ }^{8}$. Postanowiono bowiem, że obowiązek obrony spadnie tym razem nie tylko na barki rycerstwa, lecz poddanych: włościan i mieszczan9. Powołano zatem do życia instytucję pie-

7 Sejmy z lat 1658-1659 (Volumina Legum t. IV, ss. 514-619) nie zawierały żadnych norm, które choćby pośrednio byłyby realizacją ślubów królewskich. „Zastępczo” wiązały się z tym konstytucje przeciw arianom, obwinianym o wszystkie zło w Rzeczypospolitej. Zarzucane później królowi liczne przypadki „uszlachcania chłopów” na Ukrainie były wynikiem ugody hadziackiej z 1658 r., a nie ślubów lwowskich Jana Kazimierza.

8 Konstytucja Sejmu ekstraordynaryjnego 1655 r. O pospolitym ruszeniu (Volumina Legum, t. IV, s. 482-483).

9 Powołana do życia przez króla Stefana Batorego piechota wybraniecka straciła już znaczenie, sabotowana przez posesorów królewszczyzn lub zamieniana na podatek łanowy. Konstytucja Sejmu z 1649 r. p.t. „Włoki wybranieckie” (ibidem, t. IV, s. 280-281) stwierdzała, iż „Rzeczpospolita z wybrańców żadnego pożytku nie ma". 
choty łanowej. Była ona pomyślana z rozmachem; mogła stanowić początek późniejszych o stulecie form powszechnej rekrutacji wojskowej ${ }^{10}$. Na razie zaś była wyrazem narastającej wśród szlachty niechęci do pospolitego ruszenia i tendencji do ograniczenia tego obowiązku.

Z każdych piętnastu łanów lub włók, nie tylko z królewszczyzn, ale także z dóbr duchownych i szlacheckich mieli być dostarczani rekruci "do wojny sposobni". Miasta, w zależności od swego rozmiaru obowiązane były dostarczać jednego żołnierza z dwudziestu pięciu do pięćdziesięciu „dymów”, a królewszczyzny winne były zaopatrywać to wojsko w wozy, po jednym na pięciu piechurów. Każdy piechur miał być uzbrojony w muszkiet z zapasem kul i prochu, szablę, siekierę; zabierał nadto ze sobą (nieokreślonej bliżej) żywność na pół roku.

Na sejmiki nałożono obowiązek, aby określały „barwę”, czyli jednolite umundurowanie piechurów. Sejmiki miały też mianować oficerów, oczywiście spośród szlachty osiadłej. Zaniedbano nałożyć na nich obowiązek, ażeby taki regiment piechoty $\mathrm{z}$ danego powiatu odpowiednio przećwiczyć, choćby $\mathrm{w}$ posługiwaniu się bronią palną. Nie zwrócił też na to uwagi król, który znał się na sprawach wojskowych.

Zaopatrzenie piechurów w siekiery pozwala przypuszczać, że obok udziału w walce pełnić oni mieli służby, które później nazwane zostały saperskimi: budowali szańce i umocnienia. Wiele uwagi poświęcono temu, by piechota łanowa nie domagała się w "ciągnieniu” wyżywienia od miejscowej ludności, wozów czy "stacji”.

Wiadomo, że piechota łanowa znalazła się, obok pospolitego ruszenia, w obozie pod Ujściem, chyba tylko po to, aby właśnie sypać szańce, zza których nikt się potem nie bronił. Po kapitulacji zbędni już łanowcy powracali do swych wsi i przypuścić wolno, że częste późniejsze skargi szlachty ziemian na uzbrojone „kupy swawolne” dotyczyły związanych z tym ekscesów.

Konfederacja tyszowiecka, zawiązana przez hetmanów z końcem grudnia 1655 r., powoływała do walki ze Szwedami wszystkie stany. Korzystając z konstytucji o piechocie łanowej, nakazywała dostarczanie piechoty w znacznie zwiększonej liczebności: jednego żołnierza z pięciu łanów. Nie chciano jednak pamiętać o tym, że król Stefan zapewniał piechocie wybranieckiej zwolnienie od wszelkich powinności poddańczych, a nawet wypłatę żołdu ${ }^{11}$.

Powołanie do walki piechoty łanowej miało rychłe i poważne skutki. Już z końcem 1655 r., zwłaszcza na wieść o szwedzkim ataku na Jasną Górę, pojawiła się chłopska partyzantka; związek tego zjawiska z powołaniem do życia i uzbrojeniem nowej formacji wojskowej jest wyraźny. Niewiele później, w cza-

10 Konstytucja Sejmu ekstraordynaryjnego 1655 r. Wyprawa piechoty łanowej (ibidem, t. IV, s. 480-481).

11 Por. Konstytucję Sejmu z 1578 r. Pieszy (Volumina Constitutionum, t. II, vol. 1, s. 419-420). 
sie powrotu króla Jana Kazimierza ze Śląska do kraju (a górale bronili króla w czasie przechodzenia przez Karpaty), w marcu 1656 r. kasztelan Stefan Czarniecki wydał uniwersał wzywający chłopów do walki ze Szwedami. Zagroził on szlachcie najsurowszymi karami, w razie gdyby powstrzymywała swych poddanych od udziału w walce. Uniwersał ten powtórzył z obozu pod Kańczugą marszałek Jerzy Lubomirski ${ }^{12}$. Korzystano z sił chłopskich i w dalszej „szarpanej wojnie” ze Szwedami.

Do tych zatem wydarzeń nawiązywał król Jan Kazimierz w Ślubach lwowskich. Problem włościański sam wchodził mu w ręce, gdy podejmował zobowiązanie, którego nie mógł, nie umiał, a chyba też i nie chciał wypełnić. Nie znamy suplik, w których włościanie domagaliby się od monarchy wypełnienia ślubowania. Nie znamy też wypadków, aby bohaterowie włościańskiej partyzantki byli po wojnie wynagradzani nadawaniem gruntu lub $\mathrm{w}$ postaci nobilitacji ${ }^{13}$. Jest rzeczą możliwą, że już sama zapowiedź ulżenia doli chłopskiej, a więc ingerencji $\mathrm{w}$ prawa ziemian do chłopskich powinności, była jedną z przyczyn wzrastającej niechęci szlachty do króla Jana Kazimierza.

Sporo natomiast uwagi król i Sejm poświęcili w tych latach miastom. Ogólnie jednak stwierdzić można, iż stan mieszczański jako całość nie uzyskał niczego; w nielicznych tylko miastach pozycja ich mieszkańców uległa polepszeniu. Nie miało to praktycznego znaczenia na skutek zniszczenia miast $\mathrm{w}$ toku działań wojennych, załamania się handlu i rzemiosła.

Były wyjątki. Zasługuje na uwagę wielki przywilej dla Lwowa z 1658 r., $\mathrm{w}$ którym Lwów ,in privilegiis et praerogativis z miasty przedniemi Krakowem $i$ Wilnem porównywamy, zachowujac ich przy dawnych prawach"14. Podobne do tego przywileje, za bohaterską postawę wobec nieprzyjaciela otrzymały później Mohylew i Kamieniec Podolski ${ }^{15}$.

Podejmowano też kosztem miast wiele decyzji, które służyć miały ku obronie Rzeczypospolitej przed kolejnym najazdem; okazało się bowiem, iż nieprzyjaciel bez poważniejszego oporu dociera do stolic Rzeczypospolitej - do Wilna ze wschodu, do Krakowa z północy. Narzucono więc na miasta obowiązek wzmocnienia swych murów i szańców obronnych.

13 Sejm z 1658 r. dokonał szeregu nobilitacji, ale żadna z nich nie dotyczyła włościan, walczących ze Szwedami w 1656 r. i w następnych latach. Wprawdzie Sejm z 1659 r. nobilitował wielu kozackich dowódców wojskowych, ale była to akcja polityczna spowodowana przez ugodę hadziacką.

14 otrzymał od papieża Aleksandra VII zaszczytny tytuł "Semper fidelis”. Jan Kazimierz dodał do tego w 1661 r. przywilej, powołujący we Lwowie jezuicką Akademię Lwowską.

15 zwolnienie od podatków. Jak się później okazało, niewiele skutków or o wzmocnieniu załogi wojskowej twierdzy kamienieckiej. 
Król, który w praktyce nie dysponował wówczas żadnymi środkami materialnymi ${ }^{16}$, oraz Sejm, który nie był w stanie bez ogromnych zaległości egzekwować dochodów Rzeczypospolitej, zdawali sobie sprawę z tego, że zniszczone i wyludnione miasta nie mogły stawić skutecznego oporu najezdnikom. Postanowiono więc wesprzeć je $\mathrm{w}$ miarę możności kosztem państwa, aby uczynić je „fortecami Rzeczypospolitej"17. Ograniczono przy tym samorząd miast, bo dowódcami załóg obronnych mieli być komendanci ze stanu szlacheckiego.

Były to wszystko postanowienia doraźne, które w niczym nie miały polepszyć stanowiska miast i mieszczaństwa w powojennej przyszłości. Jedyny ich cel polegał na tym, że król i Sejm liczyli się z tym, że znowu jakiś najazd mógłby sięgnąć aż do środka Rzeczypospolitej; miasta wówczas, a nie szlacheckie pospolite ruszenie, stałyby się główną siłą obronną.

Podsumowując to, co król uczynił dla włościan i mieszczan, stwierdzić należy, iż dalekie to było od najskromniejszej choćby reformy ustroju społecznego. Dowodziło natomiast, że monarcha zlekceważył swoją własną przysięgę, złożoną w Katedrze lwowskiej.

Należy się jeszcze parę uwag Janowi Kazimierzowi jako niefortunnemu sternikowi prac nad reformą ustroju politycznego.

Monarcha ten miał świadomość stojących przed jego Koroną zadań, ale nie miał ani koncepcji, ani środków, by tym zadaniom podołać. Ujawniło się to, jak wiadomo, od pierwszych dni po koronacji. Przy pomocy znakomitego doradcy, jakim był kanclerz Jerzy Ossoliński, Jan Kazimierz miał szanse, aby powstanie na Ukrainie zakończyć jak najmniej krwawo. Zabrakło jednak wielkiego kanclerza, który zmarł w 1650 roku. Ugoda hadziacka z 1658 roku, która byłaby owocem jego polityki, przyszła za późno.

Królowi i jego późniejszym doradcom nie udało się rozwiązać węzła sprzecznych dążeń po obydwu stronach. Polskie zwycięstwa (jak pod Beresteczkiem) powodowały, że w Rzeczypospolitej górę brali ",jastrzębie", wrogo nastawieni do ugody. Jeśli ponoszono klęski (jak pod Batohem), wrogiem ugody stawali się Kozacy. Korzyść z tej sytuacji odniosła tylko Moskwa.

Walce o obronę Rzeczypospolitej przed najazdami towarzyszyło narastające przekonanie, iż jakieś zmiany są nieuniknione. Szlachta jednak niechętna była reformom. Naruszałyby one podstawy ustroju, który uznawano za do-

16 Jan Kazimierz nie mógł w czasie „potopu” liczyć na żadne regularne dochody ze swych ekonomii. Naiwnie mówił o tym pan Pasek: „...Król Kazimierz, lubo był pan dobry, ale nigdy nie miał szczęścia do pieniędzy, po prostu nie chciały się go trzymać..." (Jan Chryzostom z Gosławic Pasek, op. cit., s. 321-322).

17 Sejm z 1658 r. (Volumina Legum, t. IV, s. 514 i nast.) stanowił, iż „fortecami Rzeczypospolitej” będą w pierwszym rzędzie: Kraków, Warszawa, Poznań, Lwów, Kamieniec Podolski, Lubowla. Osobna konstytucja zajęła się ogólnie obronnością miast, stanowiąc iż w każdym województwie winna być jedna silna twierdza. Nadto nakazywano szczególne umocnienie Krakowa, Poznania, Halicza, Brześcia („który jest wrotami do Korony Polskiej i Wielkiego Księstwa Litewskiego”). Nie pominięto wsławionej niedawno swą obroną Jasnej Góry. 
skonały - wszak, jak już w XVI w. pisał Stanisław Orzechowski, „przodkowie nasi $\mathrm{w}$ wielkiej prostocie swej takową nam rzeczpospolitą w Polszcze zbudowali, iż przeciwko rzeczy naszej pospolitej insze państwa i krolestwa tyrannides i niewolstwa jawne są"18. Natomiast reformy inaczej nazwane, naprawiające to co eufeministycznie traktowano jako "egzorbitancje”, miały większe szanse realizacji.

Sejm 1658 r. poprzedziła konwencja senatorska z udziałem przedstawicieli szlachty; postanowiła ona, iż popierać będzie na Sejmie ważne decyzje. Obok doraźnych kwestii, jak zapłata zaległości dla wojska, a przy tym reforma systemu skarbowego, do głównych zadań zaliczono usprawnienie Sejmu, ażeby „jak za przodków naszych był”. Szło więc o zniesienie albo przynajmniej ograniczenie liberum veto, do konkretnego, rozważanego właśnie projektu. Sformułowana też została propozycja, aby przeobrazić instytucję senatorów rezydentów w stałą radę przy królu. Propozycja ta, wespół z usprawnieniem pracy urzędów koronnych i nadwornych, zmierzała do wzmocnienia i urealnienia władzy centralnej. Były to - jak pisał Zbigniew Wójcik - plany reform „daleko idące, rzec można bardzo śmiałe, co stanowiło niewątpliwie o ich słabości"19.

W tym właśnie momencie król i dwór popełnili decydujący błąd. Podkreślając fakt oczywisty, iż wygasła właśnie rodzina Wazów, popierano plan elekcji vivente rege. Nie wykluczone, iż Jan Kazimierz chciał w ten sposób ciężar reformy, której potrzebę pojmował, ale realizacji obawiał się, przerzucić na barki swego następcy. Może też sądził, że ów następca, władca silny i zdecydowany, szybko ukróci szlachecką anarchię.

Dla szlachecko-magnackiej opozycji był to nie tylko atak na instytucję „,wolnej elekcji", ale oczywisty plan zaprowadzenia w Rzeczypospolitej absolutum dominium. Opór przeciwko temu spowodował, iż nakreślony wcześniej program reform został odłożony na dalszą przyszłość, czyli praktycznie upadł.

Znaczną winę za ten stan rzeczy ponosił król Jan Kazimierz. Obwiniano go tak dalece, że pojawiło się żądanie wypowiedzenia mu posłuszeństwa. Do tego nie doszło, gdyż abdykował - co w kręgach anarchicznej opozycji porównywano do zdrady.

Abdykując, zdawał sobie sprawę z całego pasma swoich błędów. Nie przewidział natomiast, jak dalece abdykacja ta zaszkodzi władzy monarszej w Rzeczypospolitej.

18 Dyalog albo rozmowa około exekucyi Polskiej Korony, przez Stanisława Orzechowskiego, wyd. K. J. Turowskiego, Kraków 1858, s. 21.

19 Z. Wójcik, op. cit., s. 135. 


\section{Bibliografia}

\section{Źródła}

Dyalog albo rozmowa około exekucyi Polskiej Korony, przez Stanisława Orzechowskiego, wyd. K. J. Turowskiego, Kraków 1858.

Kordecki A., Nowa Gigantomachia, wyd. z 1859.

Panowanie Jana Kazimierza. Teksty źródłowe, Kraków 1924.

Pasek J. Chryzostom z Gosławic: Pamiętniki, wyd. J. Czubek, PAU, Kraków 1929.

Volumina Legum t. IV, Petersburg 1859.

\section{Literatura}

Czapliński W., Polski słownik biograficzny, t. X, Wrocław 1962-1964.

Wasilewski T., Ostatni Waza na polskim tronie, Katowice 1984.

Wójcik Z., Jan Kazimierz Waza, Wrocław 1997. 